\title{
Essay
}

\section{Køn og arbejde i kønsforskningens barndom og ungdom i Danmark}

\author{
Karen Sjørup
}

Dette essay overvejer, hvordan de overordnede tendenser i feministisk teori og ligestillingspolitisk praksis har påvirket forskningen om køn på arbejdsmarkedet gennem de sidste 30 år. Fra en overvejende marxistisk til en overvejende socialkonstruktionistisk tilgang. Man kan tale om at denne forskning både har reflekteret de kolossale forandringer, der er sket i kvinders arbejdsmarkedstilknytning, og de politiske og mentalitetsmæssige forandringer, som er sket. Samtidig er der sket en stærk akademisering af forskningen, der har trukket den væk fra en kvindepolitisk dagsorden, men til gengæld også har modnet forskningsfeltet.

$\mathrm{D}_{\mathrm{a}}^{\mathrm{a}}$ a dansk kønsforskning spirede frem i løbet af 1970'erne, skete det i forlængelse af og i stor udstrækning i samklang med udviklingen af den danske 1970'er kvindebevægelse, der som regel omtales med samlebetegnelsen 'rødstrømpebevægelsen', skønt den havde næsten lige så store splittelser og enkeltorganiseringer som resten af den datidige venstrefløj.

Kønsforskningens udvikling skete ligeledes parallelt med udviklingen på universiteterne efter 1968 med fagkritik, opgøret med positivismen og siden den marxistiske bølge i den danske universitetsforskning. Forståelsen af kønnet og de samfundsmæssige forskelle på kvinders og mænds situation indeholdt imidlertid betydelige udfordringer i forhold til at forstå det personlige i forhold til det samfundsmæssige, forstå kønnet i forhold til klasser, at forstå frigørelse og ligestilling i forhold til traditionelle kønsroller. Dette affødte en patriarkatsteoretisk diskussion i begyndelsen af 1980'erne og en mere psykoanalytisk diskussion ikke mindst om, hvordan man skulle forstå moderskabets rolle, samt endelig post-perioden med på den ene side den Habermas'ske tyske kritiske teori i modspil til den Foucaultinspirerede socialkonstruktivistiske teori.

Dertil kom udviklingen i kvinders faktiske forhold i relation til uddannelse og arbejde. I 1970'erne og fremover kom der mange kvinder i gang med uddannelse på universiteter og mellemlange uddannelser, mens den økonomiske krise i midten af 1970'erne - oliekrisen - satte skub i nedlæggelser af arbejdspladser i de arbejdsintensive industrier, herunder ikke mindst mange kvinders arbejdspladser. Mange frygtede dengang, at kvinderne ville blive skubbet tilbage til kødgryderne, men resultatet var nærmest det modsatte, kvinder fandt be- 
skæftigelse i den stærkt voksende servicesektor både i det offentlige og det private.

I den tidlige kønsforskning talte vi om, at det drejede sig om 'forskning om, af og for kvinder'. Vi ville forske med kvinder som objekt, som kvinder selv som forskningssubjekter og virke for kvinders frigørelse. Dermed kom forskningsobjektet også faretruende tæt på os selv og vort eget frigørelsesprojekt, hvilket også førte til en gennem mange år og måske stadig lav vurdering af kønsforskningens forskningsresultater som såvel bias'ed som subjektive.

Siden kom det i 1990'erne til en kritik fra sorte feminister, som tog afstand fra de hvide vestlige feministers tro på feminismen som en entydig sag, en sag for alle kvinder. Dette har siden bidraget til en selvkritisk dekonstruktion af de entydige sandheder, som 1980'er feminismen havde fremanalyseret og dermed også af forestillingen om en særlig sag for kvinder, der var bundet - essentielt - til kønnet. Siden kom mandeforskningen til og øvede tilsvarende et pres på og en kritik af de feministiske sandheder.

Efter de første tilløb til en kvindeforskning, som opstod blandt kvinderne på universiteterne, hvor man ikke længere ville finde sig $\mathrm{i}$ at sidde på de yderste bænke og vente på at blive gift - og som bl.a. resulterede i bogen Kan kvinder loese? (DSF 1974), der havde de universitetsstuderende kvinder både som objekter og subjekter for forskningen - flyttede blikket sig til arbejderkvinderne, hvis situation blev endevendt $i$ en række skrifter, samtidig med at man forsøgte at danne alliancer med arbejderkvinderne. I forlængelse af den herskende marxistiske lære betragtede man arbejderkvindernes situation som et udtryk for, at kapitalen i 1960'ernes højkonjunktur havde mobiliseret arbejdskraftreserven for siden at kunne skaffe sig af med dem igen i en lavkonjunktur.

\section{Kvindearbejdet $\mathbf{i}$ industrien}

1970'ernes oliekrise og deraf følgende arbejdsløshedsbølge bekræftede delvis disse antagelser. I 1976 startede venstrefløjsforlaget Modtryk i Århus en serie om kvindearbejde og kvindekamp. Den første udgivelse i denne serie var Kvinders arbejds- og levevilkår - belyst gennem kvinderne i tobaksindustrien, af Ruth Emerek og Birte Siim fra det nyoprettede Aalborg Universitet(scenter).

Forfatterparret skriver i bogens forord, at de bryder med den traditionelle universitetsforskning gennem et mere aktivt samarbejde med fagbevægelsen i Aalborg.

Det var vi nu mange, der gjorde i disse år, også på RUC og KU, hvor jeg havde min ansættelse. I universitetscentrenes første år var det meget populært for studerende og forskere at samarbejde med fagbevægelsen. Det var i tråd med den marxistiske/socialistiske ånd, der rådede på disse universiteter.

Men i lyset af den herskende marxistiske eller historisk materialistiske videnskabsteoretiske overbevisning var det de produktive arbejdere, i dette tilfælde kvinderne i tobaksindustrien, man kastede sig over.

Og i overensstemmelse med den videnskabsteoretiske overbevisning gik man historisk til værks og beskrev udviklingen i tobaksindustrien i løbet af det 20. århundrede i form af strukturomlægning og mekanisering, fra arbejdsintensiv til kapitalintensiv drift.

Det dekvalificerede de mandlige arbejdere og arbejdet kunne overtages af ufaglærte kvindelige arbejdere. Der skete dog det uventede, at lønningerne for de to køn tilnærmede sig hinanden, i og med at andelen af faglærte arbejdere og dermed mandlige arbejdere gik ned.

Bogen beskæftiger sig således med en række af de temaer, som stadig er herskende i kønsforskningen om arbejdsliv, nemlig tendensen til at det konkrete udtryk for 
kønsarbejdsdeling skifter, mens en ny kønsarbejdsdeling etableres, ligelønsdebatten, som i dette tilfælde førte til en tilnærmelse af kvindelønninger til mandelønningerne, og endelig kvinders dobbeltarbejde.

Men på dette tidspunkt var det i højere grad kapitalens dobbeltudbytning end mændenes manglende deltagelse i husarbejdet, man koncentrerede sig om:

\section{"Inddragelsen af arbejderkvinderne som løn- arbejdere udvidede kapitalens udbytningsfelt og gav arbejderkvinderne to arbejdspladser: Arbejderkvinderne udbyttes som kvinder og arbejdere $i$ såvel produktion som reproduk- tion. Den dobbelte arbejdsbyrde betyder, at arbejderkvinderne yder en form for mer- arbejde - som de ikke får betaling for. $\mathrm{Da}$ kvinderne ikke får betaling for hjemmearbej- det, må det betyde, at kvindernes arbejds- kraft betales under dens voerdi" (Emerek \& Siim 1976, 96).}

Kritikken var altså på dette tidspunkt ikke rettet mod de mandlige arbejdere og deres manglende deltagelse i husarbejdet, selv om denne jo var stærkt medvirkende til kvinders dobbeltarbejde, det var det abstrakte begreb 'kapitalen', som var skurken.

Der blev i samme år (1976) skrevet en anden bog om kvindearbejde og kvindeorganisering i konfektionsindustrien 1890-1914 (Broch 1977), som på samme vis indtog en historisk materialistisk position, men navnlig beskæftigede sig med kvinders hjemmearbejde som overgangsfase fra håndværk til industri, og dermed overgangen fra mandearbejde til kvindearbejde - før konfektionsindustrien endelig i 1970'erne og fremefter blev udlagt til i første omgang Sydeuropa og siden asiatiske lande.

Der var i de skrifter, der i midten af 1970'erne beskæftigede sig med de kvindelige arbejderes vilkår, også et væsentligt kampperspektiv, hvor arbejderkvindernes kamp blev søgt forenet med kvinderne i den nye kvindebevægelses kamp.

Jeg var i samme år selv med til at skrive bogen Kvinder i kamp (Giese 1976), hvor jeg særligt beskæftigede mig med plattepigernes kamp på den Kongelige Porcelænsfabrik, efter at jeg gennem længere tid havde interviewet og observeret arbejdernes aktioner og også støttet denne aktivt på linje med mange andre arbejdsmarkedsforskere, kvinder fra kvindebevægelsen og den socialistiske venstrefløj.

Tilsvarende tog bogen om kvinderne $i$ tobaksindustrien også udgangspunkt i strejkerne på tobaksfabrikken Skråen i Aalborg.

Man kan sige, at man begreb forholdet mellem arbejder og kapital ud fra et marxistisk kampperspektiv, som satte arbejder og kapital i modsætning til hinanden og opererede med et klart 'vi' og 'de' perspektiv, hvor vi selv forstod os som en del af 'vi' perspektivet, skønt vi selv som universitetsstuderende og kandidater så udpræget var borgerskabets børn.

Jeg skrev selv i det samme år min afsluttende afhandling i sociologi med titlen Kvinder og klasser (Sjørup 1976).

Jeg forholdt mig i denne afhandling til det historiske faktum, at den voksende mekanisering og senere automatisering i industrien ikke førte til, at kvinderne blev trukket tilbage til kødgryderne, sådan som de fleste antog i forlængelse af midthalvfjerdsernes økonomiske krise, men at kvinderne derimod i endnu større omfang fandt ansættelse i det arbejde, som man kaldte uproduktivt, nemlig i servicesektoren ikke mindst i den offentlige omsorgssektor.

Og selv om arbejdsløsheden toppede netop i de år, så skete der i langt højere grad en mobilisering af kvinder til det post-industrielle samfunds hovederhverv, mens mændene fortsat $\mathrm{i}$ højere grad var at finde $\mathrm{i}$ industrisamfundets tekniske og industrielle områder. 


\section{Kvinder - det fleksible køn}

Men udviklingen var primært en mobilisering af de gifte kvinder til arbejdsmarkedet, og denne foregik i stigende omfang gennem deltidsarbejde i den offentlige sektor, på kontor eller i butik. En udvikling mod deltidsarbejde for kvinder, som den kvindelige del af fagbevægelsen (især Kvindeligt Arbejderforbund) i mange år havde modsat sig, da kvinderne her med god ret mente, at en kvinde skulle kunne forsørge sig selv af sit arbejde.

Brita Foged og Randi Marcussen skrev i 1984 Det fleksible køn - kvinder i butik og på kontor, hvor de netop argumenterer for, at det fleksible arbejde, som kvinderne på den tid leverede, var et udtryk for en ny tids arbejdsliv, hvor arbejdsgivernes behov for en fleksibel arbejdskraft gik hånd i hånd med kvindernes behov for at forhandle og indrette deres arbejdstid efter familiens og deres egne krav om ligeværdighed og indbyrdes solidaritet.

De argumenterer for, at kvinder modsat mænd ikke har et hierarkisk syn på arbejdet:

"De [kvinderne] ønsker et arbejdsmiljø, hvor alle bliver orienteret om, hvad der foregår, og er selv fleksible, når arbejdet og isaer kollegerne kroever det. Ud fra deres medleven $i$ hinandens liv er de parat til at afløse og hjoelpe hinanden. Ligevaerdigheden er kernen $i$ deres solidaritetsbegreb" (Foged \& Marcussen 1984,157$)$.

Foged og Marcussen kom hermed til at udtrykke en ny tendens i kønsforskningen i overgangen fra 1970'erne til 80'erne, nemlig en vis grad af heroisering af kvinderne for deres særlige arbejdskultur, deres kvindefællesskab og særlige vilkår. Dermed var man også på vej bort fra opfattelsen af de kvindelige arbejdere som aktører i en omfattende klassekamp, nu sås de snarere som en lønarbejdergruppe, der søgte autonomi og selvudfoldelse gennem arbejdet.

\section{Kvinders særlige arbejdskultur}

Denne tendens kunne allerede ses i den tyske Ulrike Prokops bog Kvindelige livssammenhoenge, der blev oversat til dansk i 1978, og som for mange var en åbenbaring, da den beskæftigede sig med kvinders særlige produktivkræfter, evne til at skabe hjem og til at yde omsorg, og som altså så disse kvaliteter som produktive kvaliteter og ikke, som den ortodokse marxistiske teori, som uproduktive reproduktive funktioner, der primært varetoges i hjemmet og som sådan indgik i værdien af mandens arbejde.

Dette indebar også en kritik af kategorien kvinde som en offer-kategori og tilsvarende nye teoretiske og metodiske forsøg på at etablere en sammenhæng mellem et klasse- og kønsmæssigt undertrykkelsessystem. Især spillede Heidi Hartmanns The Unhappy Marriage between Marxism and Feminism (1979) en væsentlig rolle i forståelsen af, hvordan kapitalismen og patriarkatet virkede sammen. Dette blev udgangspunktet for diskussionen om 'patriarkatsteori' og dermed også nogle skel mellem en ren marxistisk opfattelse af undertrykkelsesforholdene og en feministisk opfattelse, som udpegede patriarkatet som hovedfjenden.

Hartmanns teoretiske nybrud handlede om at sammenkoble marxistisk teori med psykoanalytisk teori, som langt hen ad vejen universaliserede kønsrelationerne bl.a. i form af, at den ødipale konflikt og incesttabuet blev betragtet som universelle forskelsskabende kategorier. Dermed voksede også en mere psykoanalytisk, freudiansk og jungiansk interesse frem i analyserne især i forståelsen for kvinders særlige omsorgsorientering eller mere negativt som en forståelse for moderskabet som et potentielt meget magtfuldt forhold. 
Dette førte til en række analyser, som tog udgangspunkt i det særlige kvindelige omsorgsarbejde og et fokus på blandt andet sygepleje som udtryk for dette oversete kvindearbejde, som traditionelt havde været omgærdet af en religiøst baseret kaldsetik, der samtidig betød, at kvinderne blev meget ringe betalt for deres arbejde, og samtidig at omsorg for andre opfattedes som et anliggende, der udførtes af ugifte kvinder enten som erstatning for egen familie eller som træning til moderskabet.

\section{Kvinder i mandefag}

Imidlertid kom der også andre boller på suppen i midten af 1980'erne, der langt hen ad vejen splittede det danske kønsforskningsmiljø, der beskæftigede sig med kvinders arbejde. Analyser fra Det Økonomiske Råd pegede på, at udviklingen i kvinders beskæftigelse især i den offentlige sektor ville udgøre et stadigt stigende flaskehalsproblem, som ville medfører et voksende arbejdskraftproblem i håndværk og industri.

Dette gik hånd i hånd med Arbejdsgiverforeningens politik og Jernindustriens Arbejdsgivere, som i 1985 agiterede for flere kvindelige medarbejdere i jernindustrien med slagord som "Jernet er varm på pigerne" og en video, hvor nogle unge piger danser rundt på et værkstedsgulv iført lyserøde kedeldragter. Da der i 1981 blev ansat ligestillingskonsulenter i alle arbejdsformidlingens områder, blev det at få kvinderne til at søge over i mandefagene da også den væsentligste opgave.

Det betød, at man fra centralt hold begyndte at omskole kvindelige arbejdere til traditionelle mandefag. Dette førte bl.a. til det store nordiske projekt BRYT (Dahlerup 1991), som gik ud på at etablere en række forsøg med at engagere kvinder i mandefag og overtale unge kvinder til at søge håndværkeruddannelser i stedet for at uddanne sig til pædagog, folkeskolelærer eller inden for sygepleje.

Dette delte kønsforskerne i to lejre, den, som deltog aktivt i dette forsøg på at nedbryde det kønsopdelte arbejdsmarked, og den, som heri så en nedvurdering af de kvindelige arbejdspraksisser.

I første omgang lykkedes det også at mobilisere kvinder i stort tal til uddannelser inden for håndværksfagene. Men kort tid efter kunne man konstatere, at dette førte til en meget stor ledighed for kvinderne i disse fag, hvor der i forvejen var en ret stor ledighed, og at man samtidig kom til at mangle sygeplejersker, lærere og pædagoger. Dette skete især fordi man i Undervisningsministeriet på samme tid gennemførte en detaljeret styring af adgangen til uddannelserne, hvilket resulterede i adgangsbegrænsning i netop de fag, som hurtigt kom til at mangle arbejdskraft. Dette skete ikke mindst på baggrund af Det Økonomiske Råds markante fejlslutninger i rapporten fra 1983.

\section{Kvindelige akademikere - karriere og lederskab}

I 1990'erne blev det i stigende grad også accepteret, at de kvindelige kønsforskere rettede blikket på sig selv og deres egen situation som kvindelige akademikere. Dette skete som en følge af den udvikling, som i løbet af 1990'erne gjorde, at kvinderne udgjorde majoriteten af de studerende på universiteterne og siden også majoriteten af færdiguddannede akademikere, som samtidig kunne erfare, at de både på universiteterne og de øvrige offentlige og private arbejdsmarkeder stadig stødte hovedet mod det glasloft, der usynligt men dog effektivt forhindrede kvinderne i at nå de topposter og den høje løn, som mændene formåede.

Dette har resulteret i en række studier af, hvordan kønsforskellen fremtræder, når kvinder bliver akademikere, ledere eller 
forskere. Disse studier har registreret en tilbagevendende tendens til, at køn reproduceres som forskel (Emerek et al. 1997) bl.a. i kraft af, at kønsarbejdsdelingen synes at blive reproduceret på stadig nye niveauer, således at kvindelige læger interesserer sig mere for dialogen med patienterne, børnesygdomme og gynækologi, mens mandlige i højere grad fokuserer på kirurgi, forskning og ledelse (Sjørup 1998).

Studierne dokumenterer, at kvindelige forskere synes at nå et glasloft i løbet af karrieren, således at en kandidatproduktion på $60 \%$ kvinder gennem den såkaldte saksemodel reduceres til $10 \%$ kvinder blandt professorerne (Henningsen 2002), og at kvindelige ledere synes at nå mellemniveauerne og særligt de HR-relaterede lederjobs, mens der blandt topledere både i det offentlige og det private er færre end $10 \%$ kvinder.

\section{Køn som social konstruktion i arbejdslivet}

I midten af1990'erne skete imidlertid en omfattende vending bort fra den materialistiske og psykologisk orienterede kønsforskning frem til en socialkonstruktionistisk teoretisk platform, der i højere grad betragtede de kønsmæssige forskelle på arbejdsmarkedet som en social produktion af køn, der byggede på en implicit påstand om biologisk essentielle forskelle. Denne nye orientering var præget af den amerikanske feministiske filosof Judith Butler (1990 og 1993), der betragter kønnet som en 'performance' - altså de særlige måder at skabe køn i genkendelige former, som sker gennem handlinger og sprog.

Tilsvarende er Butler blevet udnævnt som ophav til begrebet 'queer', der udtrykker en mindre dramatisk forskelstænkning mellem køn, mellem homoseksuelle og heteroseksuelle udtryk. Denne queer-tænkning har udmøntet sig i en queer-feminisme, der udtrykker sig med usikre kønskoder og kropstegn, som også har inspireret den moderne teaterdramatik.

Judith Butler inspirerede den danske socialpsykolog Dorte Marie Søndergaard i disputatsen Tegnet på kroppen (1996), som tager udgangspunkt i københavnske universitetsstuderendes 'måder at gøre køn' i midten af 1990'erne.

I denne afhandling betragtes kønnet som et mærke eller et tegn på kroppen snarere end som en biologisk forskel. Samtidig udgør disse kønnede handlinger en subjektiveringsproces, hvorunder det enkelte individ hhv. underkaster sig og bemestrer de kulturelle normer og koder.

Denne afhandling og tilgang har skabt en hovedstrømning i den yngre kønsforskning i Danmark i dag. F.eks. undersørger Mette Lykke Nielsen i sin ph.d. afhandling Far mor og ingeniør (2008), hvordan køn konstitueres som en forskellig tilgang til familie-arbejdslivsdilemmaet for mandlige og kvindelige ingeniører:

"Afhandlingen viser hvordan en gruppe ingeniører taler sig frem gennem ansvarligheder og nødvendigheder, der skriver sig ind $i$ relativt kønstraditionelle arbejdsdelinger. Arbejdsdelinger hvor lønarbejde etableres som førstehed, igennem mange af de mandlige ingeniørers subjektiverende bevagelser, mens familieliv og ulønnet arbejde etableres som førstehed $i$ flere af de kvindelige ingeniørers orienteringer" (Lykke Nielsen 2008, 346).

Denne konstruktionistiske tilgang, som er dominerende blandt den yngre generation af særligt kvindelige kønsforskere, er blevet kritiseret for sin overvejende teoretiske og i mindre grad feministiske tilgang, som dermed også er med til at afpolitisere kvindekampen eller at gøre analyserne mindre tilgængelige for folk udenfor den snævre universitære verden. 


\section{Intersektionalitet}

Begrebet intersektionalitet opstod som et konkret udtryk for den sorte amerikanske feminismes oprør mod den dominerende hvide feminisme (Crenschaw 1994), som i høj grad formåede at abstrahere fra såvel klasse- som etniske og kulturelle forskelle på kvinders og mænds vilkår.

Denne tilgang ser således i højere grad på, hvordan fænomener som køn, klasse og etnicitet forstærker eller modvirker hinanden som elementer i en konkret underordnings- eller dominansposition, således så sorte kvinder på en række parametre klarer sig bedre end sorte mænd. På tilsvarende vis kan man se, hvordan begrebet 'muslim' i Danmark i dag etableres som en underordningsposition for kvinder, men til gengæld en truende og potentiel voldelig position for mænd.

Imidlertid er der en ofte påvist tendens til, at det at sætte fokus på etniske forskelle kan føre til, at kønsperspektivet underordnes eller forsvinder fra analyserne. Men samtidig bliver det muligt med denne tilgang at arbejde med begreber om kollektive forskelle og mangfoldighed i feministiske politiske analyser (Lykke 2005).

\section{Mod en ny kropsmaterialistisk kønsteori?}

Frem mod årtusindeskiftet er der imidlertid vokset en ny kropsmaterialistisk teori frem navnlig med inspiration fra den belgiske filosof Luce Irigaray. Denne kritiserer den af-materialisering, som er sket af kønnet $i$ såvel den marxistiske som den socialkonstruktionistiske kønsforskning, som har gjort kroppen og kropsforskellen mellem mand og kvinde usynlig og dermed kønnet og kønsforskellen til en tom skal, der først fyldes ud, når det enkelte individ agerer $\mathrm{i}$ forhold til et kulturelt bestemt billede af køn.
Lykke (2008) fremhæver den australske kropsfeminisme, som netop arbejder med kvindekroppens forskellighed, men samtidig forsøger at fastholde denne i en ikkedualistisk relation til mandskroppen:

"For at komme ud over den dualistiske filosofi må vi ifølge Grosz overskride konstruktionismens udgangspunkt $i$ det sociokulturelle $k \emptyset n$ og alternativt tage kropslighed og kroppe $i$ deres individuelle og multiple (kønnede, racialiserede etc.) specificiteter som udgangspunkt for diskussion af subjektivitet og identitet" (Lykke 2008, 88).

En anden del af denne kritik har været inspireret af Simone de Beauvoirs begreb om 'kroppen som situation', dvs. om kroppen som det fænomenologiske udgangspunkt for den kønnede erfaring. Det er bl.a. den norske Toril Moi (1999) og den danske Lilian Munk Rösing (2005), som har fremhævet dette forsøg på at begribe sammenvævningen af krop og kultur i den konkrete konstruktion af køn. Og man kan jo sige, at fag som sygepleje og omsorg i høj grad benytter sig af de kvindelige kropsudtryk som en særlig tilgang til at yde omsorg, som er forbundet med såvel moderskabet som med en opfattelse af et kvindeligt religiøst kald.

\section{Afslutning}

Udviklingen i kønsforskningen om arbejdsliv har langt hen ad vejen reflekteret de voldsomme forandringer, der over et par generationer er sket i kvinders livsforløb i forhold til uddannelse og arbejde. Fra den nuværende ældre generation, hvor de fleste kvinder ikke fik uddannelse og som gifte kvinder primært blev opfattet som hjemmearbejdende husmødre, til den unge generation, hvor kvinderne er mere veluddannede end mændene, og hvor de samtidig forventer en arbejdskarriere, der lever op til deres 
høje krav og samtidig muliggør et ligestillet forældreskab og samtidig en mindre monogam og heteronormativ seksualitet.

Samtidig har kønsforskningen også reflekteret en videnskabsteoretisk rutschetur fra den positivistiske registrering af forskelle, over den marxistiske og materialistiske, og over en psykoanalytisk orienteret kønsforskning, til den i dag udbredte diskursteoretiske og socialkonstruktionistiske tilgang.

Man kan også tale om, at der er sket en modning af kønsforskning til en egentlig videnskabelig tradition med en mangfoldighed af teoretiske inspirationer og et mere reflekteret fugleperspektiv på kønsforskningens udvikling. Selv om kønsforskningen ofte beskyldes for at fastholde kvinder i et entydigt offerperspektiv, er dette langtfra nogen entydig sandhed. Som en ny disciplin med et omfattende apparat af videnskabelige inspirationer og en tværvidenskabelig oprindelse er der snarere tale om en kompleksitet, der er vanskelig at formidle så håndgribeligt som 1970'ernes entydige klassekampsperspektiv.

Samtidig kan man sige, at konflikterne om lønningerne i omsorgsfagene i foråret 2008 tydeligt har påpeget nogle af de håndfaste følger af den manglende anerkendelse af disse funktioner som værdifulde og efterspurgte professionelle funktioner. De har også ganske tydeligt påpeget den dobbelthed, som består i på den ene side den systematiske underbetaling af kvinder, og af mænd, der arbejder i kvindedominerede fag og sektorer, og på den anden side kvin- dernes nye selvbevidsthed i forhold til deres rolle som efterspurgt arbejdskraft på et arbejdsmarked, som hidtil har ment at man kunne bekvinde disse sektorer med den passive kvindelige arbejdskraft.

Da de danske kvinder i stigende grad søger uddannelse, der kvalificerer dem på højere niveauer, har man med noget held formået at få kvinder med mellemøstlig oprindelse til at forstå, at de gemmer på uudnyttede kvindelige omsorgsressourcer, således at der i dag gennemføres omfattende programmer for at rekruttere disse kvinder til SoSu-fagene. Dette lykkes overraskende godt, mens den tilsvarende indsats for at rekruttere fædrene og brødrene til den her i finanskrisen så skrantende byggeindustri har langtfra den samme succes. Dermed er intersektionalitetsperspektivet også ganske synligt i relationen mellem køn og etnicitet på arbejdsmarkedet.

Det er dog alligevel markant, at kønsforskningen om arbejdsmarkedet ikke længere er så direkte politisk fokuseret, som den var i 1970'erne. Kønsforskerne i den yngre generation disciplineres ligesom andre universitetsforskere i retning af en publiceringspraksis, som gør internationale peer reviewede tidsskrifter til den højest prioriterede publiceringsform. Dermed foregår debatterne om kvinders omsorgsorientering, om udviklingen i ligeløn og om familie-arbejdslivskonflikter også i langt højere grad i universitetsfora på internationalt plan og i mindre grad som stemmer i en national og lokal politisk debat.

\section{REFERENCER}

Broch, Birte (1977): Kvindearbejde og kvindeorganisering. Kvinder i konfektionsindustrien 18901914, København, Selskabet til forskning i arbejderbevægelsens historie.

Butler, Judith (1990): Gender Trouble: Femi- nism and the Subversion of Identity, London, Routledge.

Butler, Judith (1993): Bodies that Matter: On the

Discursive Limits of "Sex", London, Routledge. Crenshaw, Kimberlé Williams (1994): Mapping 
the Margins, Intersectionality, Identity Politics, and Violence against Women of Color, i Martha Fineman \& Roxanne Mykitiuk (eds.): The Public Nature of Private Violence, London, Routledge, 93-120.

Dahlerup, Drude (1991): Det Nordiske BRYTProjekt 1985-89. Beskrivelse og evaluering af projektets forløb og organisering, København, Det Nordiske BRYT-Projekt.

DSF (1974): Ka' kvinder loese? DSF, Kvindeprojektet tekst nr. 1, København.

Emerek, Ruth \& Birte Siim (1976): Kvinders arbejds- og levevilkår - belyst gennem kvinder $i$ tobaksindustrien, Århus, Modtryk.

Emerek, Ruth et al. (1997): Brydninger. Perspektiver på det kønsopdelte arbejdsmarked, København, Arbejdsmarkedsstyrelsen.

Foged, Brita \& Randi Marcussen (1984): Det fleksible køn. Kvinder i butik og på kontor. København, Tiderne Skifter.

Giese, Susanne (red.) (1976): Kvinder i kamp, København, Tiderne Skifter.

Hartmann, Heidi (1979): The Unhappy Marriage between Marxism and Feminism. Towards a more Progressive Union, i Capital and Class, 3, 8, 1-33.

Henningsen, Inge (2002): Køn i den akademiske organisation, Arbejdspapir 1-13, København, Institut for Statskundskab.

Lykke, Nina (2005): Nya perspektiv på intersek- tionalitet. Problem och möjligheter, i Kvinnovetenskapelig tidsskrift, 26, 2-3, 7-17.

Lykke, Nina (2008): Kønsforskning. En guide til feministisk teori, metodologi og skrift, København, Forlaget Samfundslitteratur.

Lykke Nielsen, Mette (2008): Far, mor og ingeniør. Tilblivelser af hverdagsliv mellem arbejds- og familieliv, Roskilde, Forskerskolen i Livslang Læring, Roskilde Universitet.

Prokop, Ulrike (1978): Kvindelige livssammenhoeng. Om strategiernes indskroenkethed og de umådelige ønsker, Århus, GMT.

Moi, Toril (1999): What is a Woman, Oxford, Oxford University Press.

Munk-Rösing, Lilian (2005): Kønnets katekismus, Roskilde, Roskilde Universitetsforlag.

Sjørup, Karen (1976): Kvinder og klasser, Afhandling, Sociologisk Institut. Københavns Universitet, (Upubliceret).

Sjørup, Karen (1998): The Gender Relation and Professionalism in the Postmodern World: Social Brotherhood and Beyond, i Drude van der Fehr, Bente Rosenbeck \& Anna Jónasdóttir (eds.): Is there a Nordic Feminism - Nordic Feminist Thought on Culture and Society, London, UCL Press.

Søndergaard, Dorte Marie (1996): Tegnet på kroppen. Køn: Koder og konstruktioner blandt unge voksne i akademia, København, Museum Tusculanum.

Karen Sjørup er lektor ved Institut for Samfund og Globalisering, Roskilde Universitet e-mail: kasj@ruc.dk 